\title{
Angelika Wodecka-Hyjek
}

Uniwersytet Ekonomiczny w Krakowie

e-mail:wodeckaa@uek.krakow.pl

\section{PRZEDSIĘBIORCZOŚĆ PUBLICZNA PRZESŁANKĄ KSZTALTOWANIA MODELI BIZNESU W SEKTORZE PUBLICZNYM* PUBLIC ENTREPRENEURSHIP AS THE PREMISE FOR SHAPING BUSINESS MODELS IN THE PUBLIC SECTOR}

DOI: $10.15611 /$ pn.2018.538.37

JEL Classification: L26, L33.

\begin{abstract}
Streszczenie: Aktualne rozważania w zakresie problematyki modeli biznesu dotyczą w szczególności sektora biznesu. Novum w tym zakresie stanowi teza o potrzebie kształtowania modeli biznesu w sektorze publicznym i organizacjach non profit. Eksploracja zagadnień dotyczących przedsiębiorczości publicznej pozwala zauważyć związek pomiędzy działaniami przedsiębiorców publicznych a dążeniem do formułowania modeli biznesu. Celem artykułu jest ukazanie potrzeby i specyfiki implementacji koncepcji modeli biznesu w sektorze publicznym w kontekście przedsiębiorczości publicznej. W opracowaniu wskazano definicję oraz usystematyzowano aktualne uwarunkowania przedsiębiorczości publicznej wraz z odniesieniem do koncepcji wartości publicznej, scharakteryzowano kontekst zależności koncepcji modelu biznesu i przedsiębiorczości, a następnie zaprezentowano założenia modelu biznesu w sektorze publicznym, wskazano jego atrybuty oraz dokonano oceny implementacji w tym obszarze. Artykuł stanowi rezultat kwerendy aktualnej literatury przedmiotu w zakresie podjętego problemu.
\end{abstract}

Słowa kluczowe: przedsiębiorczość publiczna, koncepcja modeli biznesu, model biznesu w sektorze publicznym.

Summary: Current reflections in the field of business models concern in particular the business sector. Novum in this regard is a thesis about the need to shape business models in the public sector and non-profit organizations. Exploration of issues related to public entrepreneurship allows to note the relationship between the activities of public entrepreneurs and the desire to formulate business models. The aim of this article is to identify the need and specifics of the implementation of the concept of business models in the public sector in the context of public entrepreneurship. The study identifies and systematizes the current conditions of public

* Publikacja została sfinansowana ze środków przyznanych Wydziałowi Zarządzania Uniwersytetu Ekonomicznego w Krakowie w ramach dotacji na utrzymanie potencjału badawczego. 
entrepreneurship with reference to the concept of public value, characterizes the context of the concept of business model and entrepreneurship, and then presents the assumptions of the business model in the public sector, its attributes and evaluation of implementation in this area. The article is the result of a query of the current literature on the subject in terms of the problem.

Keywords: public entrepreneurship, concept of business models, business model in the public sector.

\section{Wstęp}

Próby definiowania i eksplorowania problematyki przedsiębiorczości publicznej podejmowane były w literaturze światowej od połowy lat 80 . XX stulecia, początkowo w pracach badaczy zagranicznych, a następnie badaczy polskich ${ }^{1}$, i nadal są kontynuowane. Zasadniczym nurtem rozpoznanym w tej dziedzinie stało się ukazanie specyfiki i uwarunkowań, zarówno w zakresie fenomenu przedsiębiorczości, jak i roli przedsiębiorcy w funkcjonowaniu organizacji publicznych. Przegląd badań w zakresie przedsiębiorczości publicznej pozwala zauważyć, że z jednej strony przedsiębiorcy publiczni są mniej zainteresowani zyskiem i doświadczają mniejszej autonomii w działaniu niż przedsiębiorcy prywatni, chociaż zazwyczaj łatwiej pozyskują zasoby, aby realizować swoje pomysły, z drugiej natomiast, podobnie jak przedsiębiorcy prywatni, są poszukiwaczami nowych możliwości i odczuwają silną potrzebę zdobywania osiągnięć, co czyni z nich agentów zmian [Ramamurti 1986; Sadler 2000]. Jednocześnie kluczowym zadaniem współczesnych menedżerów jest zwiększanie wartości, a istotnym zagadnieniem na tle zarządzania współczesnymi organizacjami projektowanie modeli biznesu sprzyjających kreacji wartości [Jabłoński 2013, s. 29].

Zatem, jeżeli cechę wspólną przedsiębiorców, zarówno w sektorze publicznym, jak i w sektorze prywatnym, stanowi poszukiwanie i wykorzystywanie okazji w celu generowania wartości, wyłania się nowy kontekst badań współczesnej teorii przedsiębiorczości publicznej, którego celem jest uzasadnienie potrzeby rozwoju i wykorzystania modelu biznesu w sektorze publicznym [Najmaei, Sadeghinejad 2016, s. 50]. Stwierdzenie to stanowi tezę niniejszego opracowania, a wyeksplikowaniem istotności i trafności podjętego problemu jest opinia A. Frączkiewicz-Wronki i P. Cziury [2017, s. 65], którzy zakładają, że ,jeśli organizacja posiada sprawdzony sposób tworzenia, dostarczania i wykorzystywania wartości, oznacza, że posiada również model biznesu. Przekonanie, że model biznesu to pojęcie stworzone wyłącznie na potrzeby organizacji biznesowych jest błędne... Bez znaczenia jest fakt, czy działa w sektorze nastawionym na zysk, czy też nie, wszystkie bowiem organizacje mają model biznesu, chociaż być może jeszcze nie wszyscy menedżerowie to sobie uświadamiają".

${ }^{1}$ Szerzej: [Wodecka-Hyjek 2017]. 
Cel niniejszego opracowania stanowi ukazanie potrzeby i specyfiki implementacji koncepcji modeli biznesu w sektorze publicznym w kontekście przedsiębiorczości publicznej. W artykule rozstrzygnięto kwestie terminologiczne oraz dokonano usystematyzowania aktualnych uwarunkowań przedsiębiorczości publicznej wraz z odniesieniem do koncepcji wartości publicznej, uwypuklono kontekst zależności koncepcji modelu biznesu i przedsiębiorczości, nakreślono istotę i rosnące znaczenie koncepcji modeli biznesu w funkcjonowaniu sektora publicznego. W zasadniczej części opracowania wyspecyfikowano warunki kształtowania, atrybuty modelu biznesu w sektorze publicznym oraz zarysowano proces transformacji przedsiębiorczości publicznej w model biznesu. Artykuł stanowi rezultat kwerendy aktualnej literatury przedmiotu, krajowej i zagranicznej, w zakresie podjętego problemu. Pozycje przytoczone w tekście zostały wyszukane za pomocą baz własnych polskich bibliotek naukowych oraz bazy EbscoHost, pochodzą z recenzowanych monografii i czasopism naukowych.

\section{Istota i uwarunkowania przedsiębiorczości publicznej}

I. Boyet [1996, s. 49] zauważa występowanie przedsiębiorczości w sektorze publicznym w warunkach decentralizacji władzy i uprawnień, przy jednoczesnej realokacji własności zasobów, pomimo niesprzyjających warunków otoczenia. W opinii autorki „napędzana” jest ona przez jednostki, które mają zdolność do dostrzegania nowych możliwości w zakresie zaspokajania potrzeb interesariuszy, a ich celem jest osiągniecie wysokiego poziomu zadowolenia społecznego. C. Kearney, R.D. Hisrich i F. Roche [2007, s. 279] ujmują przedsiębiorczość publiczną jako proces występujący wewnątrz organizacji publicznej, w którego rezultacie podejmowane są działania o charakterze innowacyjnym, takie jak: doskonalenie istniejących lub wprowadzanie nowych usług, technologii, metod i technik zarządzania, doskonalenie bądź unowocześnienie istniejących strategii, podejmowanie ryzyka i proaktywność. P.G. Klein, J.T. Mahoney, A.M. McGahan i Ch.N. Pitelis [2010, s. 6] koncepcję przedsiębiorczości $\mathrm{w}$ warunkach sektora publicznego rozumieją przez pryzmat dostrzegania możliwości osiągnięcia zysku, podejmowania decyzji w warunkach niepewności, wprowadzania innowacji. Jako podstawę teoretyczną do zrozumienia przedsiębiorczości publicznej proponuje się przedsiębiorczość wewnętrzną (korporacyjną, intraprzedsiębiorczość). $\mathrm{W}$ takim ujęciu przedsiębiorczość $\mathrm{w}$ sektorze publicznym jest procesem tworzenia wartości dla obywatela (użytkownika usług) poprzez nierutynową (czy nawet unikalną) kombinację zasobów, będących zarówno w gestii publicznej (społecznej), jak i prywatnej, użytkowanych po to, aby wychwycić i wykorzystać szanse i możliwości rozwoju oraz uzyskać nowe rezultaty (wyższą wartość). W takim ujęciu jest to proces (aktywność jednostek bądź zespołów) uzależniony od wielu czynników: indywidualnych (podmiotowych), organizacyjnych i zewnętrznych (politycznych, ekonomicznych, społecznych, edukacyjnych) [Kraśnicka 2009, s. 54]².

\footnotetext{
${ }^{2}$ Por. [Wodecka-Hyjek 2017].
} 
Odniesienie rezultatów przedsiębiorczości organizacji sektora publicznego do kreowania wartości pozwala wysunąć tezę, że podobnie jak w przedsiębiorstwie, organizacje sektora publicznego tworzą wartość, a proces ten wymaga zgromadzenia zasobów, wypracowania odpowiedniego systemu wzajemnych zależności czy współpracy z interesariuszami. Działania te, poprzez analogię z sektorem prywatnym, postrzegać można jako kształtowanie modelu biznesu. Należy zaznaczyć, że w sektorze publicznym podstawę definiowania stanowi wartość publiczna. Pojęcie wartości publicznej do dyskursu akademickiego wprowadził M.H. Moore [1995] w latach 90. ubiegłego stulecia w pracy pt. Creating Public Value. Podstawowym założeniem w koncepcji autora jest skonstruowanie trójkąta strategicznego ukazującego kreację wartości publicznej przez wskazanie korelacji pomiędzy trzema zasadniczymi elementami: wartością, którą powinna dostarczać organizacja, legitymizacją działań i wsparciem, które organizacja otrzymuje od społeczeństwa, oraz jej zdolnością operacyjną. W zamierzeniu M.H. Moore'a wartość publiczna stanowi kryterium oceny pracy menedżera publicznego, a poprzez analogię do dóbr prywatnych ma stanowić efekt produkcji dóbr i usług sektora publicznego, pomniejszonych o koszt ich wytworzenia. Istotnym problemem koncepcji jest trudność pomiaru wartości publicznej. Wartość dóbr sektora prywatnego kreowana jest przez konsumentów podejmujących dobrowolne decyzje o ich zakupie, tymczasem w sektorze publicznym nie ma tak rozumianej dobrowolności. Moore przyjmuje, że również decyzje konsumentów dóbr publicznych są dobrowolne (choć nie indywidualne), gdyż dokonywane są w ramach procesu demokratycznego. Wybory dokonywane w ramach tego procesu są kolektywnie i kreują „my”, które może prawomocnie decydować o wykorzystaniu zasobów oraz określaniu celów. W takim ujęciu wartość publiczna może zostać zdefiniowana jako nadwyżka netto tego kolektywnego konsumenta, porównującego koszty pewnych działań z wartością, którą mu one przynoszą. Kluczowe jest tutaj pojęcie kolektywnego podmiotu, które w pracy Moore'a postrzegane jest w trzech znaczeniach [Moore 1995, s. 30, za: Musialik, Musialik 2013, s. 142; Ćwiklicki 2017, s. 86-96]:

- „my” jako byt istniejący osobno od członków społeczności,

- „my” jako politycy będący partnerami menedżera sektora publicznego,

- „my” jako procedury polityczne pozwalające przechodzić od preferencji indywidualnych do decyzji zbiorowych.

Dokonany w ramach niniejszego opracowania przegląd dotychczasowego dorobku badaczy zagadnienia przedsiębiorczości publicznej pozwala zauważyć, że specyfikę przedsiębiorczości sektora publicznego najczęściej charakteryzowano przez pryzmat uwarunkowań funkcjonowania sektora publicznego, innowacji oraz postawy przedsiębiorcy publicznego. Wśród specyficznych uwarunkowań badacze przedmiotu akcentują szeroką rozpiętość i zróżnicowanie celów, mnogość interesariuszy, ograniczoną autonomię i elastyczność, transparentność i przejrzystość wydatkowania środków publicznych, kulturę organizacyjną, która z biurokratycznej przekształca się w kulturę proinnowacyjną, brak systemów motywacyjnych zorientowanych na pobudzanie zachowań sprzyjających przedsiębiorczości, wpływy polityczne, regulacje 
prawne i konieczność przestrzegania procedur czy rosnące znaczenie oczekiwań co do skuteczności i efektywności działania [Kearney i in. 2009, s. 29]. Wdrażanie innowacji w tym obszarze stanowi szansę zwiększania wartości publicznej, chociaż ograniczana jest ona akcentowaniem odpowiedzialności za podejmowane decyzje, ryzykiem dysponowania środkami publicznymi, niemożnością pokonania sztywnych zasad i procedur, zależnością od dostawców z sektora prywatnego lub organizacji non profit czy nieumiejętnością dostrzeżenia długookresowych korzyści [Røste, Miles 2005, s. 26-29]. Przedsiębiorca publiczny zatem wykorzystuje zasoby w coraz nowszy sposób, aby zmaksymalizować efektywność i skuteczność działania; tworzy wartość dla obywateli, łącząc zasoby w celu wykorzystania szans o charakterze społecznym; identyfikuje i wykorzystuje możliwości zwiększania wartości poprzez innowacje w niepewnym otoczeniu [Leyden, Link 2015, s. 7-11].

\section{Zależności koncepcji modelu biznesu i przedsiębiorczości}

Podstawę koncepcji modeli biznesu w teorii i praktyce nauk o zarządzaniu stanowi zdefiniowanie terminu „model biznesu”. Przegląd definicji modelu biznesu pozwala zauważyć, że pomimo dużego zintensyfikowania prac w tym zakresie i szeregu podobieństw w definiowaniu nie przyjęto jednego, spójnego ujęcia tego problemu. A. Osterwalder i Y. Pigneur [2012, s. 18] reprezentują pogląd, że model biznesu opisuje przesłanki wskazujące na sposób, w jaki organizacja tworzy wartość oraz zapewnia i czerpie zyski z tej wytworzonej wartości. S. Cyfert i K. Krzakiewicz [2011, s. 100] uważają, że model biznesu określa logikę powiązań tworzonych pomiędzy zasobami będącymi w dyspozycji organizacji a działaniami kreującymi wartość dla szeroko rozumianych klientów. Z kolei T. Falencikowski [2013, s. 36] twierdzi, że model biznesu jest wzorem stanowiącym konceptualnie opracowany i wyodrębniony wieloskładnikowy obiekt, ujmujący prowadzenie biznesu w sposób uproszczony, poprzez opisywanie logiki tworzenia wartości dla klienta i przechwytywania tych wartości przez przedsiębiorstwo. Powołane definicje akcentują relacje przyczynowo-skutkowe pomiędzy zasobami i głównymi procesami, w których zasoby wykorzystywane są w celu osiągnięcia efektów, oraz eksponują wątek tworzenia wartości dla interesariauszy, co stanowi kluczowy punkt odniesienia. Zatem każdy model biznesu obejmuje specyficzny zbiór działań, zasobów, sposobów ich organizacji, kształtowanych w celu generowania wartości, z uwzględnieniem powiązań z szerokim gronem interesariuszy.

Wśród licznych zagadnień problemowych podejmowanych w zakresie problematyki modeli biznesu [Zott i in. 2011] obecne są, ujmowane w różnych kontekstach, badania w zakresie powiązania koncepcji modeli biznesu i teorii przedsiębiorczości. Aspekt zrozumienia znaczenia modeli biznesu oraz jego powiązań z innowacjami (oprócz strategii i teorii ekonomi), jako atrybutu przedsiębiorczości, dostrzec można w rozważaniach D.J. Teece'a [2010, s. 186], który zauważy1, że wdrażanie innowacji, zwłaszcza technologicznych, będzie udane tylko wtedy, gdy ich rezultaty będą kreować 
wartość, która będzie interesująca dla klienta pod względem jakości i ceny. W procesie tym istotna jest kreatywność technologiczna, która zależy od pomysłowości wynalazcy, a przedsiębiorczość istotnie wpływa na kształtowanie modelu biznesu. Znaczenie innowacji i przedsiębiorczości w kształtowaniu modelu biznesu wyeksponowali także Ch. Zott, R. Amit i L. Massa [2011, s. 1033], powołując koncepcję otwartej innowacji, która wychodzi poza granice wnętrza organizacji i czerpie pomysły z zewnątrz. Przedsiębiorczość polega tutaj na tworzeniu wartości opartej na współpracy z otoczeniem, wspólnym generowaniu pomysłów, które wynikają z dzielenia się wiedzą i informacją. G. George i A.J. Bock [2011, s. 85, 88] z kolei zauważyli wyraźny związek pomiędzy kształtowaniem modelu biznesu a przedsiębiorczością $\mathrm{w}$ organizacji, postawami przedsiębiorców oraz procesami współtworzenia i wykorzystania szansy w organizacji, jak również efektywnością organizacyjną. Wyeksponowali kontekst rozumienia modelu biznesu jako związku pomiędzy innowacjami a tworzeniem wartości, jak również wątek badań kognitywnych pomiędzy dostrzeganiem okazji i jej wykorzystaniem. Za szczególnie interesujące w perspektywie dalszych badań uznali kwestie dotyczące zależności pomiędzy zmianą modelu biznesu a wykorzystywaniem szans oraz wpływem postaw przedsiębiorczych na kształtowanie modelu biznesu. A. Najmaei i Z. Sadeghinejad [2016, s. 53] badania dotyczące modeli biznesu i ich powiązań z przedsiębiorczością ujmują $\mathrm{w}$ dwóch perspektywach: poznawczej i reifikującej. Perspektywa poznawcza sugeruje, że model biznesu to schemat poznawczy, mentalna reprezentacja rzeczywistości biznesu w umyśle przedsiębiorcy. Model biznesu służy tutaj za poznawczy punkt odniesienia, którego kluczowymi funkcjami są zmniejszenie niepewności i ukierunkowanie działań na rzecz przedsiębiorczości. Przedsiębiorcy wykorzystują modele biznesu do opracowania opisowych charakterystyk tego, czym jest ich działalność. Model biznesu staje się wówczas źródłem narracji na temat działań przedsiębiorczych, wykorzystania możliwości i opracowania przepisu na osiągnięcie zysku. Jego funkcjonalność wykracza poza charakter opisowy i staje się performatywna. Działania na rzecz przedsiębiorczości odróżniają przedsiębiorców od osób niebędących przedsiębiorcami. Druga perspektywa, reifikująca, odnosi się do urzeczowienia modelu biznesu i zwrócenia uwagi na system działań wykonywanych przez daną organizację, strukturę zasobów i jej powiązań z partnerami. Powołane dywagacje pozwalają zauważyć, że przyjęte przez autorów perspektywy stanowią również próbę rozróżnienia statycznego i dynamicznego spojrzenia na model biznesu. Rozważania w tym zakresie podjęli B. Demil i X. Lecocq [2010, s. 227-246]. W ujęciu statycznym model biznesu rozpatrywany jest na poziomie abstrakcyjnym i konceptualnym, stanowi wzorzec, wskazówkę, a jego główną funkcją jest umożliwienie opisu i klasyfikacji. Stanowi zatem wyraz urzeczowienia modelu biznesu, w którym wyeksponowane są komponenty składowe i sposób ich zorganizowania. Dynamiczna natura modelu biznesu akcentuje jego zdolność do zmian wraz ze zmieniającymi się warunkami otoczenia, jak również zmiany w ramach poszczególnych komponentów. Zauważyć można tutaj wpływ działań przedsiębiorczych, które są rezultatem pomysłowości, kreatywnego myślenia, proaktywności czy skłonności do podejmowania 
ryzyka. Przegląd literatury przedmiotu sugeruje też konieczność rozróżnienia pojęcia strategii i modelu biznesu. Model biznesu, jako pojęcie, odzwierciedla charakter statyczny zjawiska, opisuje bowiem schematy - wzorce działania (ramy, układ relacji itp.) w sposób bardziej abstrakcyjny, natomiast strategia, czyli sposób realizacji, opisuje charakter dynamiczny zjawiska, wskazując na elastyczność zachowań przedsiębiorstwa w zmiennych warunkach, w jakich ono funkcjonuje [Nogalski 2009, s. 7-8].

\section{Założenia modelu biznesu w sektorze publicznym w perspektywie przedsiębiorczości publicznej}

Wątek adaptacji koncepcji modeli biznesu do specyfiki sektora publicznego jest słabo rozpoznany w literaturze przedmiotu. Pionierską propozycję w tym zakresie na gruncie polskim zaproponował T. Falencikowski [2018, s. 211-224], przyjmując założenie, że koncepcje zarządzania wypracowane na gruncie przedsiębiorstw for profit mogą zostać wykorzystane do doskonalenia usług świadczonych przez organizacje publiczne. W ramach prowadzonego wywodu autor uzasadnił, że wykorzystanie teorii modelu biznesu może przyczynić się do doskonalenia funkcjonowania organizacji publicznych w zakresie usług świadczonych na rzecz obywateli, będących de facto ich klientami, oraz zaproponował autorską koncepcję modelu biznesu, adekwatną do potrzeb zdefiniowanych w opracowaniu rodzajów organizacji publicznych.

W kontekście powiązania z przedsiębiorczością publiczną interesującą propozycję adaptacji modelu biznesu dla potrzeb sektora publicznego przedstawili A. Najmaei i Z. Sadeghinejad [2016, s. 53-54]. Autorzy przyjęli następujące założenia:

- każdy przedsiębiorca potrzebuje modelu biznesu - bez modelu biznesu przedsiębiorca, zarówno w sektorze prywatnym, jak i publicznym, nie może wykorzystać okazji i zaistniałych sposobności - wykorzystanie okazji, po ich rozpoznaniu, wymaga podjęcia działania przez jednostki przedsiębiorcze, które opracują model konceptualny i zorganizują niezbędne zasoby. Model biznesu i wykorzystanie okazji są z sobą powiązane i nie mogą być traktowane oddzielnie;

- model biznesu należy rozpatrywać w ujęciu dynamicznym, ze szczególnym uwzględnieniem ciągłego dostosowywania do zmieniających się warunków otoczenia; korekty związane są z oceną aktualnych rozwiązań i dostępności zasobów, dotyczą subiektywnych ocen zagrożeń i sposobności, które wpływają na kształt modelu biznesu i kierują dalszymi działaniami przedsiębiorcy.

W konsekwencji powyższych założeń autorzy ujęcie dynamiczne modelu biznesu utożsamiają z procesem przedsiębiorczości. Propozycja ta wymaga uwzględnienia indywidualnych zdolności przedsiębiorców, którzy działają niezależnie i podejmują samodzielne działania dostosowania modelu biznesu do zidentyfikowanych okazji, antycypowania wpływu zmiany na jego funkcjonowanie oraz komponenty i ich powiązania. Ponadto autorzy zaznaczają, że przedsiębiorczość publiczna odnosi się do organizacji publicznych, które działają w specyficznych warunkach, quasi-rynków 
uzależnionych od czynników instytucjonalnych i politycznych, a nie stricte ekonomicznych. Z uwagi na zróżnicowanie celów oraz dostępność zasobów i ich konfiguracji rezultaty działalności organizacji w sektorze publicznym, jako wyniki przyjętego modelu biznesu, autorzy utożsamiają z obszarami wpływu przedsiębiorczości publicznej [Klein i in. 2010, s. 7]. Szczegółowy zakres atrybutów modeli biznesu w sektorze publicznym prezentuje tabela 1 .

Tabela 1. Atrybuty modelu biznesu w sektorze publicznym

\begin{tabular}{|c|c|}
\hline Kryterium & Charakterystyka \\
\hline Cel & $\begin{array}{l}\text { - logiczne wykorzystanie okazji i szans w celu realizacji interesu } \\
\text { publicznego. }\end{array}$ \\
\hline Proces kształtowania & $\begin{array}{l}\text { - ujęcie dynamiczne, } \\
\text { - rozwój i dostosowanie modelu zorientowane na kreowanie wartości } \\
\text { publicznej. }\end{array}$ \\
\hline Obszar wykorzystania & $\begin{array}{l}\text { - organizacje publiczne, } \\
\text { quasi-rynki. }\end{array}$ \\
\hline Wykonawca & $\begin{array}{l}\text { - } \text { polityk, } \\
\text { - administrator, } \\
\text { - menedżer publiczny. }\end{array}$ \\
\hline Zasoby & $\begin{array}{l}\text { - zasoby publiczne, prywatne i inne, } \\
\text { - cechy/kompetencje przedsiębiorcze. }\end{array}$ \\
\hline Kluczowa funkcja & $\begin{array}{l}\text { ukazanie, w jaki sposób przedsiębiorca publiczny pozyskuje, } \\
\text { utrzymuje, rozwija i zarządza zasobami niezbędnymi do urzeczowienia } \\
\text { dostrzeżonych możliwości. }\end{array}$ \\
\hline Wyniki & $\begin{array}{l}\text { - nowe polityki publiczne, rozwiązania prawne, procedury, } \\
\text { - nowe organizacje/instytucje realizujące zadania publiczne, } \\
\text { - twórcze zarządzanie zasobami publicznymi, } \\
\text { - budowanie współpracy pomiędzy sektorem publicznym a biznesem } \\
\text { w realizacji celów społecznych. }\end{array}$ \\
\hline Determinanty rozwoju & $\begin{array}{l}\text { - siły polityczne sprzyjające zapewnieniu/rozwojowi dóbr publicznych, } \\
\text { - zmiany instytucjonalne, } \\
\text { - zmiany technologiczne, } \\
\text { - cykle/kadencje polityczne. }\end{array}$ \\
\hline
\end{tabular}

Źródło: opracowanie i tłumaczenie własne na podstawie [Najmaei, Sadeghinejad 2016, s. 55].

Na kanwie powołanych rozważań wywnioskować można, że transformacja (rys. 1) aktu przedsiębiorczości w model biznesu w sektorze publicznym warunkowana jest dynamicznym postrzeganiem modelu biznesu, co spowodowane jest przede wszystkim koniecznością zorientowania organizacji publicznych na wyniki, zmianami w wymaganiach interesariuszy oraz oczekiwaniami w zakresie wdrażania innowacji.

Warunkiem koniecznym tworzenia modelu biznesu przez menedżera publicznego o zdolnościach przedsiębiorczych jest nie tylko dostrzeganie szans i okazji, lecz przede wszystkim umiejętność oceny możliwości jej zrealizowania, czyli urzeczowienia 


\section{Koncepcja mentalna}

przedsiębiorczości

\section{Ujęcie dynamiczne}

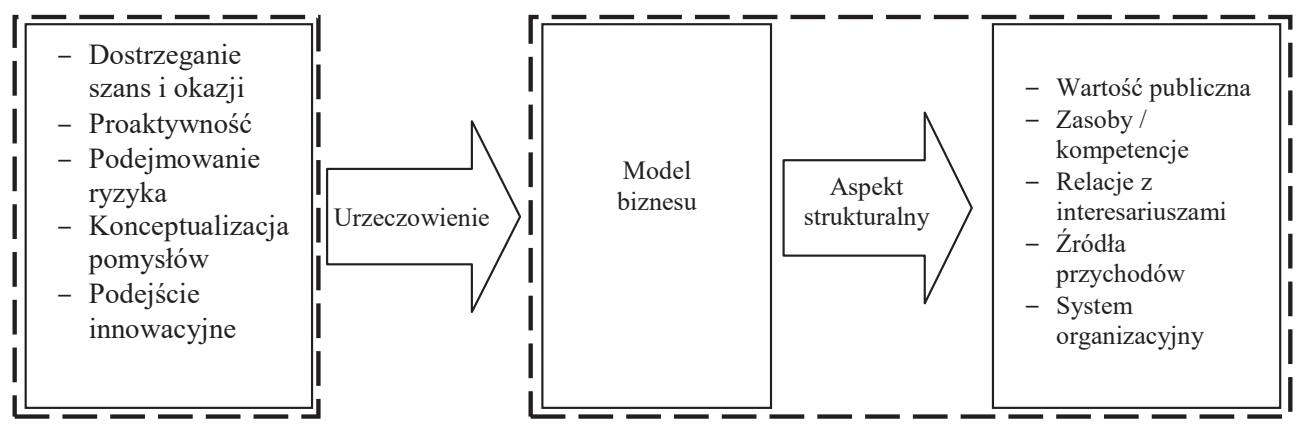

Rys. 1. Transformacja przedsiębiorczości w model biznesu

Źródło: opracowanie własne.

koncepcji mentalnej, wyrażonej zdolnościami pozyskania niezbędnych zasobów, zbudowania relacji zewnętrznych i wewnątrzorganizacyjnych, które są podstawą prawidłowo skonstruowanego modelu biznesu, kreującego wartość publiczną. Ponieważ optymalny model biznesu, gwarantujący organizacji najlepsze wyniki, nie jest z góry znany, jego konceptualizacja wymaga bieżącego monitorowania i reorganizacji na podstawie uczenia się, analizowania informacji, obserwacji warunków otoczenia, wykorzystywania różnych kombinacji zasobów, zarówno publicznych, prywatnych, jak i tych, które tkwią w potencjale trzeciego sektora. Wymaga też konsultacji i oceny zgodnie z założeniami nowoczesnych modeli zarządzania publicznego.

\section{Zakończenie}

Zasygnalizowana $\mathrm{w}$ opracowaniu potrzeba wykorzystania koncepcji modeli biznesu w sektorze publicznym w perspektywie zaprezentowanych rozważań stanowi konsekwencję przedsiębiorczości publicznej. Przedsiębiorczość wyrażona poprzez eksponowanie cech jednostki przedsiębiorczej, takich jak dostrzeganie okazji, proaktywność, podejmowanie ryzyka czy innowacyjność, stanowi o podejmowaniu działania w określonym celu, który w przypadku sektora publicznego ma charakter wieloaspektowy. Ukazane w opracowaniu determinanty przedsiębiorczości publicznej istotnie warunkują również proces kształtowania modeli biznesu w sektorze publicznym. Transformacja motywu mentalnego przedsiębiorcy w konkretne przedsięwzięcie wymaga sformułowania określonych ram postępowania, pozyskania zasobów, zidentyfikowania źródeł przychodów i organizacji działania, które przyczynią się do osiągnięcia sukcesu, w postaci wartości publicznej, a proces ten poprzez analogię z sektorem prywatnym utożsamiany jest z konstruowaniem modelu biznesu. Kształtowanie modeli biznesu w sektorze publicznym może przyczynić się 
do uporządkowania działalności organizacji poprzez opracowanie wzorca i schematów postępowania, gwarantujących transparentność i rozliczalność oraz realizację celów społecznych. Model biznesu postrzegany jako konstrukt dynamiczny pozwoli przedsiębiorcy publicznemu na identyfikowanie wpływu zmian zachodzących w otoczeniu, wpływających na wizerunek organizacji i relacje z interesariuszami. Ponadto utrzymanie i rozwój modelu biznesu sprzyja wdrażaniu efektywnych sposobów zarządzania, w których kontekstem dominującym jest wykorzystanie nowoczesnych metod i narzędzi, eksponowanie partycypacji obywateli w podejmowaniu decyzji, wprowadzanie innowacyjnych rozwiązań oraz efektywne wydatkowanie środków publicznych. $Z$ uwagi na to, że problem ten w literaturze przedmiotu jest słabo rozpoznany, a powoływany wątek ma charakter sygnalizacyjny, dalsze rozważania w tej kwestii mogą stanowić interesujący obszar badawczy.

\section{Literatura}

Boyett I., 1996, The public sector entrepreneur - a definition, International Journal of Public Sector Management, no 9 (2), s. 36-51.

Cyfert S., Krzakiewicz K., 2011, Wykorzystanie koncepcji modeli biznesu w zasobowej teorii firmy, [w:] Krupski R. (red.), Rozwój szkoły zasobowej zarządzania strategicznego, Prace Naukowe Wałbrzyskiej Wyższej Szkoły Zarządzania i Przedsiębiorczości, Wałbrzych, s. 99-107.

Ćwiklicki M., 2017, Public Entrepreneurship and Its Role in Public Value Creation, Problemy Zarządzania, nr 1 (65), s. 86-96.

Demil B., Lecoq X., 2010, Business model: Toward a dynamic consistency view of strategy, Long Range Planning, no 43 (2-3), s. 227-246.

Falencikowski T., 2013, Spójność modelu biznesu. Koncepcja i pomiar, CeDeWu, Warszawa.

Falencikowski T., 2018, Od modelu biznesu przedsiębiorstwa do modelu biznesu organizacji publicznej, Przedsiębiorczość i Zarządzanie, Wydawnictwo SAN, t. XIX, z. 6, cz. 2, s. 211-224.

Frączkiewicz-Wronka A., Cziura P., 2017, Możliwość wykorzystania modeli biznesu do ksztaltowania wizerunku przedsiębiorstw społecznych, Zeszyty Naukowe Uniwersytetu Ekonomicznego w Katowicach, nr 313, s. 61-73.

George G., Bock A.J., 2011, The business model in practice and its implications for entrepreneurship research, Entrepreneurship Theory and Practice, no 35 (1), s. 83-111.

Jabłoński M., 2013, Kształtowanie modeli biznesu w procesie kreacji wartości przedsiębiorstw, Difin, Warszawa.

Kearney C., Hisrich R., Roche F., 2007, Facilitating public sector corporate entrepreneurship process: a conceptual model, Journal of Enterprising Culture, no 15 (3) September 2007, s. 275-299.

Kearney C., Hisrich R., Roche F., 2008, A Conceptual Model of Public Sector Corporate Entrepreneurship, International Entrepreneurship and Management Journal, no 4 (3), s. 295-313.

Klein P.G., Mahoney J.T., McGahan A.M., Pitelis C.N., 2010, Toward a theory of public entrepreneurship, European Management Review, no 7 (1), s. 1-15.

Kraśnicka T., 2009, Przedsiębiorczość sektora publicznego i jej uwarunkowania, [w]: Frączkiewicz-Wronka A. (red.), Zarzadzanie publiczne - elementy teorii i praktyki, Wydawnictwo Akademii Ekonomicznej, Katowice.

Leyden D.P., Link A.N., 2015, Public sector entrepreneurship. U.S. Technology and Innovation Policy, Oxford University Press. 
Luke B., Verreynne M.L., Kearins K., 2010, Innovative and entrepreneurial activity in the public sector: The changing face of public sector institutions, Innovation: Management, Policy \& Practice, no 12 (2), s. 138-153.

Moore M.H., 1995, Creating Public Value, Harvard University Press, Cambridge, Massachusettes, London, England.

Musialik G., Musialik R., 2013, Kreacja wartości publicznej, Współczesne Zarządzanie, nr 2, s. 141-148.

Najmaei A., Sadeghinejad Z., 2016, Toward a theory of business models and business modeling in public entrepreneurship, [w:] Liddle J. (red.) New Perspectives on Research, Policy \& Practice in Public Entrepreneurship, Emerald Group Publishing Limited, Bingley, UK, s. 49-59.

Nogalski B., 2009, Modele biznesu jako narzędzia reorientacji strategicznej przedsiębiorstw, Master of Business Administration, t. 17, nr 2, s. 3-14.

Osterwalder A., Pigneur Y., 2012, Tworzenie modeli biznesowych. Podręcznik wizjonera, Wydawnictwo Helion, Gliwice.

Ramamurti R., 1986, Public entrepreneurs: Who they are and how they operate, California Management Review, no 28 (3), s. 142-158.

Røste R., Miles I., 2005, Differences between public and private sector innovation, [w:] Halvorsen T., Hauknes J., Miles I., Roste R. (red.), On the differences between public and private sector innovation, Publin Report, no D9, NIFU STEP, Oslo, s. 22-39, http://unpan1.un.org/intradoc/groups/ public/documents/apcity/unpan046809.pdf (14.09.2018).

Sadler R.J., 2000, Corporate entrepreneurship in the public sector: The dance of the Chameleon, Australian Journal of Public Administration, no 59 (2), s. 25-43.

Teece D.J., 2010, Business models, business strategy and innovation, Long Range Planning, no 43 (2-3), s. 172-194.

Wodecka-Hyjek A., 2017, Konceptualizacja przedsiębiorczości w sektorze publicznym - przeglad wybranych podejść, Ekonomika i Organizacja Przedsiębiorstwa, nr 7 (810), s. 59-68.

Zott C., Amit R., Massa L., 2011, The business model: Recent developments and future research, Journal of Management, no 37 (4), s. 1019-1042. 